\title{
Comparative Study between Colonial Forest Policy and the New Sustainable Forest Policy in the Republic of the Congo
}

\author{
Mikouendanandi Mouendo Rahmat Brice Espoire ${ }^{1}$, Wen Yali ${ }^{1}$, \\ Mouendo Nunes Rosine ${ }^{1}$
}

\begin{abstract}
${ }^{1}$ School of Economics and Management, Beijing Forestry University, No35, Qinghua East Road, Haidian District, Beijing, Peoples Republic of china, Post Code -100083

Abstract: The objective of our study on the changes that have marked the evolution of forest policy in Congo during the colonial period to the present day, based on surveys conducted in several villages, is to understand the changes in this activity. Beyond the analysis of the dynamics of forest policy change, we wanted to demonstrate an evolution of the relationships between the government, the local population and their socio-political and economic environment on the one hand, and to respond to the problem of the articulation between the dynamics of social changes in these multiethnic societies and the dynamics of the coastal space they share. Congo derives a significant set of economic, social and environmental benefits from its forests. Given the vast size and limited accessibility of its forest territory, the Government of Congo has seriously engaged in a process to improve the monitoring of forest activities on its territory in order to strengthen its capacity for sustainable forest planning and management. This commitment has included several initiatives to collect, produce, consolidate, centralize and process data sets from forest monitoring activities.
\end{abstract}

Keywords: The Republic of Congo, Colonial Forest Policy, the new Forest Policy

\begin{abstract}
Introduction
During the post-war colonial period (1945 - 1960), Congolese forest management was governed by laws and regulations established by France. The selective exploitation of these forests, focused on a limited number of species, was mainly aimed at the European market. Natural forest exploitation began in the southern part of the country, and then moved to the dense forests of the central and northern regions. Since the 1950s, Congo has implemented a policy of reforestation in dense forest areas through Limba plantations and afforestation with the introduction mainly of eucalyptus trees in the southern Congolese savannas.
\end{abstract}

Forests have long been recognized as a source of goods and services necessary for human survival. In Congo, forests have always been one of the fundamental components of the living environment of Congolese populations because of the gathering, hunting and timber products they harvest there. This can be done directly through the harvesting of firewood or timber, bush meat, vegetables and many building materials as well as objects used in cultural ceremonies. It can also be indirect since man collects these resources in order to market them and obtain financial means for subsistence and social development.
In Congo, as in all of Central Africa's forests, the exploitation of forest products (rubber, wood) has always been at the heart of the most violent forms of colonial relations, relying first on slavery and then on forced labor (Antoine; 2019). However, since the classic analysis emphasizing relations of centralperiphery domination, neo-colonial relations between "metropolises" and their former colonies no longer seem sufficiently relevant to capture the exploitationconservation paradox as it manifests itself today as a whole.

$>$ Current situation of the forest domain in Congo Located on the equator, Congo covers an area of $342,000 \mathrm{~km} 2$, largely occupied by forests. The forest area of Congo is currently estimated at about 22.5 million hectares, which represents just over $65 \%$ of the national territory $(10 \%$ of the dense forests of Central Africa, $12.3 \%$ of the forests of Africa). Continuous savannahs, observed in the centre and southwest of the country, cover an area of 12 million hectares, or about $35 \%$ of the national territory (FAO, 2006). Nearly $75 \%$ of the Congolese forest, or more than 15 million hectares, belongs to the production domain, of which 11.6 million hectares are currently allocated as forest concessions.

The tradition of wildlife conservation is well established in the country with the creation of large

This article is published under the terms of the Creative Commons Attribution License 4.0

Author(s) retain the copyright of this article. Publication rights with Alkhaer Publications.

Published at: http://www.ijsciences.com/pub/issue/2019-04/

DOI: 10.18483/ijSci.2006; Online ISSN: 2305-3925; Print ISSN: 2410-4477 
national parks and wildlife and hunting reserves or sanctuaries. The total coverage of protected areas represents more than 3.6 million hectares, or more than $11 \%$ of the national territory (Atlas forestier interactif du Congo, 2007).

The deforestation rate is low, at $0.07 \%$ per year (gross deforestation). Approximately 11,672,563 hectares represent the area of forest concessions allocated in 2014. Protected areas represent 4,528,418 hectares. The importance of the Congolese forest in economic, social and ecological terms is well established. It is therefore an important lever for the emergence of the Congolese economy and for its development (Nkodia A., 2013).

\section{1- The new development of forest policy}

In recent years, new concerns have emerged related to climate change, law enforcement, biodiversity conservation, renewable energy production, the integration of forestry into local development, technological developments and international dialogue on forests.

\subsection{Current state of the forest sector in Congo}

The current state of the forest sector shows that the Republic of Congo is making considerable progress in properly managing this national resource, which has several national and global uses and challenges. Indeed, this progress is reflected in: 50 forest concessions in the country, including

$\checkmark \quad 9$ developed concessions (29\%),

$\checkmark 20$ concessions under development (37\%),

$\checkmark \quad 21$ undeveloped concessions (34\%) and

$\checkmark \quad 17$ protected areas $(4,528,418$ ha, or $13.2 \%$ of the national territory). (ATLAS. 2007).

Forest sector management involves the management of production forests, the development of forest resources, afforestation and reforestation. On this basis, in the fight against deforestation and forest degradation, Congo had planned to afforest 1,000,000 ha by 2020 .

The main opportunities for sustainable forest management in Congo today, at the national, sub regional and international levels, are essentially:

$\checkmark$ the resumption of recruitment in the public service, which offers the forestry department the opportunity

to renew its staff;

$\checkmark$ the APV-FLEGT and REDD+ processes that offer new opportunities for improvement

the application of the law and the principles of governance, as well as the fight against deforestation and forest degradation; $\checkmark$ the national afforestation and reforestation programme (ProNAR), which aims to

planting trees on one million hectares over a 10-year period;

$\checkmark$ Congo's accession to political, technical and financial institutions working in favor of

Congo Basin forests or its partnership with others (COMIFAC, OAB, OCFSA, RAPAC, OFAC, RIFFEAC, OIBT, ATIBT);

$\checkmark$ International cooperation, through the actions it finances;

$\checkmark$ the recruitment of technical staff.

\subsection{Issues and challenges of forest reform}

Despite the many weaknesses identified, the forest is more than ever called upon to play a role major both ecologically and in terms of economic and social plans, due to its many assets. The global awareness of the need for a change in behavior due to climate change means that the Congo must continue and intensify its efforts to manage its forests located in the heart of the Bassin du Congo, the second "lung of the planet" (CNSEE, 2006). But Congolese forests must also be contribute more to the country's socioeconomic development, not only through the funds received by the Public Treasury, but also through job creation and the improvement of the living standards of people living in forest areas and, beyond that, of the entire Congolese population. The reform of national forest sector policy is thus timely in response to the changing global context, in terms of sustainable management of forest and wildlife resources and the country's development needs. But while the stakes are are high, the challenges to be met for the success of the operation are also high.

These include, but are not limited to:

$\checkmark$ redefinition of the rules accepted by all stakeholders in the management process sustainable use of forest and wildlife resources;

$\checkmark$ the application of current legislation and regulations and forest governance;

$\checkmark \quad$ strengthening the fight against climate change, in particular with the REDD+ process;

$\checkmark$ the improvement of conditions for biodiversity conservation and the development of ecotourism;

$\checkmark$ greater involvement of civil society and local and indigenous populations in forest management;

$\checkmark$ improving conditions for the supply of wood and other products to the domestic market forest and wildlife in the context of economic growth and poverty alleviation;

$\checkmark \quad$ the development and adoption of a national land use plan with the participation of all stakeholders to clearly determine the different uses assigned to each portion of the forest; 
$\checkmark \quad$ the improvement of forest research and training in order to better understand the potentialities of forest and wildlife resources in Congo and to address the problem of the quantitative and qualitative weakness of managers and field workers;

$\checkmark$ the continuation of the forest management programme and the implementation of management plans and of management;

$\checkmark \quad$ the continuation of forest certification;

$\checkmark \quad$ the promotion of agroforestry and rural and urban forestry;

$\checkmark \quad$ the overlapping exploitation of forest and mining resources;

$\checkmark$ the formalization of the informal sector;

$\checkmark$ the contribution of the forest sector to the national economy.

$\checkmark \quad$ the management of human-wildlife conflicts;

$\checkmark$ wildlife management in allocated forest concessions;

$\checkmark$ the valorization of traditional knowledge in the management of forest and wildlife resources.

\section{2- Contributions and management}

Forest management in Congo is now based on a new Forest Code that theoretically provides an effective framework for the management of forest resources (Forest Monitor Report, REM and CAGDF 2013). National legislation ensures sustainable forest production, while ensuring the conservation of forest ecosystems and taking into account the socioeconomic needs of local populations (Berkes, F. 2006).

This legal and regulatory framework, properly applied, is a key tool for the sustainable management of forest resources (FAO. 2007). However, despite these modern texts and the significant actions already undertaken, the implementation of the principles of sustainable forest resource management is still too weak. The same applies to efforts undertaken to protect biodiversity (the Republic of Congo's forest policy, 2014-2015).

The development of management plans for forest concessions (and protected areas) is too slow at a time when these ecosystems are under threat.

Substantial progress has been made. A Forest and Environment Sector Programme (FESP), currently being developed at government level, aims to implement priority actions at the national level. It could and should inject new dynamism into Congo's forest/environment sector, so that the gains are consolidated and extended to the whole country (Forest Monitor Report, EMN and CAGDF.,2013).

\section{3- Discussion}

What a difference between the colonial period and the more recent period, when the number of researchers, botanists, ecologists, ethnologists, sociologists... has increased considerably; they have studied the field and, as their function requires, have published extensively. It is certainly to be regretted that French tropical foresters are lacking in writing. But, on the one hand, as Cohen said in 1971: "Compared with members of the British Colonial Service who left a rich published record of their thought and action, the French have been taciturn. " On the other hand, Philibert Guinier, long director of the National School of Water and Forests of Nancy, several times through the French forests in general. In 1932: "If the work of the forest body has not been disseminated by many publications, voluminous didactic treatises, it is written on the ground in our forests. More than say, willingly on the level of French foresters "(HICKEL, 1932).

He returned to this theme twenty years later, in 1952 (GUINIER): "Certainly, as Parade wrote in 1855, we can regret the "rich plunder" that the foresters could and could have provided, if each of them, believing themselves to be bound by some obligation towards science, had at heart to pay off their debt. "It is to be deplored that "materials useful for the progress of sylviculture remain too generally buried in the memory or cardboard of those who have devoted a significant part of their lives to collecting them.

$>$ History and development of forest management in Congo from 1945 to the present day.

During the post-war colonial period (1945 - 1960), Congolese forest management was governed by laws and regulations established by France and organized by colonial laws and regulations. Law No. 34-61 of 20 June 1961 establishing the forestry regime in Congo was the first national legislative text. The first forestry code was adopted on 4 January 1974 by the promulgation of Act No. 004/74, amended by Act No. 32/82 of 7 July 1982 (Atlas forestier interactif $d u$ Congo.,2007.; Jérôme Ballet, et al.,2009). Law No. 34-61 of 20 June 1961 establishing the forestry regime in Congo was the first national legislative text.

he selective exploitation of these forests, focused on a limited number of species, was mainly intended for the European market (Santoir 1992). Natural forest exploitation began in the southern part of the country, and then shifted to the dense forests of the central and northern regions (Parker, M., 2004). Since the 1950s, Congo has implemented a policy of reforestation in dense forest areas through Limba plantations and afforestation with the introduction of mainly 
eucalyptus trees in the southern Congolese savannah (Ballet et al., 2005).

The first forest management actions date back to the early 1970s with the development of management plans based on annual timber harvesting programmes (Atlas forestier interactif du Congo.,2007).

The first Forest Code was adopted on 4 January 1974 by the promulgation of Law No. 004/74, amended by Law No. 32/82 of 7 July 1982 (FAO. 2006).

Nationally, Congo's first major logging operation dates back to the construction of the railway line (CFCO) between Pointe Noire and Brazzaville in the 1920s when authorization was given to cut trees to a depth of 200 meters on either side of the route, corresponding to 35,000 hectares of permits granted to the winning company. Subsequently, cutting permits were granted for supplies of firewood for locomotives.

In 1928, the first industrial logging permit was granted for 1500 hectares in Mayombe. In 1937, this exploitation intensified, and the gradual impoverishment of the Mayombe led the operators to the Chaillu massif in 1956. Today, the forests of northern Congo are being exploited. Thus, the FAO in its report published in 2002 estimates that Congo has lost $17 \%$ of its forest with a rate of deforestation of around 34,000 ha per year since 1990 .

In 1974, the new Forest Code (Act No. 004/74 of 4 January 1974) transformed Congolese forestry legislation. Considered at the time of its promulgation as one of the most modern in Central Africa, it defined forest management units (FMUs), maximum annual cutting volume (MAV), promotion of local processing, etc... While the State strengthened its role in forest policy from 1982 to 1986 , through stateowned and mixed-economy enterprises in the fields of forestry, logging and forestry industries, it withdrew from most forestry activities to the private sector from 1987 onwards (FAO Forest Policy, 2015).

In order to ensure the rational management of renewable resources, the Congolese forestry authorities have implemented a policy of sustainable exploitation of forest ecosystems and advocate for sustainable environmental protection (Congo Parks and Reserves., 2012). In this regard, strategic planning exercises such as the National Forest Action Plan (NFAP), the National Biodiversity Strategy and Action Plan (NBSAP) and the Interim Poverty Reduction Strategy Paper (IRSP) have been adopted (Nkodia A., 2013).

the 1990s were marked by the strategic document of the Ministry of Cooperation (1994), "La coopération française et la forêt du Congo". Several of its main orientations still form the basis of French policy in the forest sector with the objective of preserving the forest through its economic development (The forest policy of the Republic of Congo; 2015).

The Republic of Congo is becoming independent from rural economies, whose agricultural and economic performance is closely linked to forestry (Andriananja et al., 2006). In terms of environmental governance, there has been a two-phase evolution, which has radically changed philosophical principles since the 1990s (Kouamékan J.2014).

At present, the use of the forest estate is governed by Law No. 16/2000 of 20 November 2000 on the Forest Code. It takes into account, on the one hand, developments in forest management and environmental conservation in recent years at the international level and, on the other hand, the new socio-political context of Congo (GIREAUD, 2005). The Forest Code thus confirms the policy of sustainable management of forest ecosystems, which guarantees the sustainable production of forest products and ensures the conservation of biological diversity. In addition, the law stipulates that the transformation of the country's production must reach 85\% (Programming Framework Pays-FAO/ CONGOBrazzaville 2013-2016).

Le récent audit organisationnel des structures de l'administration forestière $(A G R E C O, 2005)$ a relevé une tendance à la modernisation du système de gouvernance du secteur forestier et du secteur financier de l'État. Du point de vue de la réglementation forestière, la loi $\mathrm{n}^{\circ} 16-2000 \mathrm{du} 20$ novembre 2000 portant code forestier et les décrets d'application du 31 décembre 2002 ont mis en place un dispositif dont les grandes lignes répondent aux défis actuels de l'aménagement et de la gestion durable des ressources (La politique forestière de la République du Congo.; 2015).

\section{4- Results}

The implementation of the national forest policy requires certain conditions to be met. Most depend on the government's commitment and the administration's efforts to give credibility to the various measures announced (Parfait Oumba.;2007). Such credibility is essential for development partners to access Congo's requests for financial support and agree to participate in the investments needed for sustainable forest sector management (Africa Future. 2010). While the principles of these reforms are in the right direction, there are still significant implementation difficulties due to shortcomings in the institutional framework (Ballet, J., et al. 2010), weak 
overall capacities and the scarcity of modern management tools to improve the operational performance of the administration. In addition, the report notes that:

$\checkmark \quad$ the absence of regulations on the modalities and level of community participation and indigenous peoples, and more broadly civil society, in the forest resource management process;

$\checkmark$ the absence of texts specifying the conditions and modalities of people's participation in the

forest classification process, from carrying out baseline studies to providing information to all stakeholders on classified areas;

$\checkmark$ the lack of concrete initiatives for the development of community forestry, despite the fact that

that the Forest Code recognizes customary ownership of forests and forest resources;

$\checkmark$ the low level of information provided to the populations themselves, to companies, to the administration and workers on the rights of local communities and indigenous peoples (user rights, land tenure);

$\checkmark$ the absence of a participatory management mechanism for conflicts related to forest management;

$\checkmark$ the lack of clear provisions on remedies and compensation in the event of restrictions on

customary forest ownership rights and customary use rights for local communities and indigenous peoples;

$\checkmark$ the slowness of the compensation mechanism in paying for damage caused by wild animals to crops.

$\checkmark$ The legal and regulatory framework remains rather vague on some key issues (e.g.

For example, forest management: The Forest Code provides little detail on operational issues. At most, he mentions the creation of structures to address this issue).

$\checkmark \quad$ The regulatory framework is sometimes not well adapted to a modern forest management

context: The structures and control mechanisms put in place do not provide the expected answers to the problem of control and information systems essential to any modern administration.

$\checkmark$ The accountability of forest concessionaires to develop and implement

forest management was carried out in an ambivalent manner in terms of role distribution.

$\checkmark \quad$ The legislation has not assigned any formal role to local communities and NGOs despite the notion that manifest of "participatory management" in all political debates and speeches. $\checkmark$ The role of international organizations (particularly conservation organizations) is not detailed:

this is the case for the

$\checkmark$ The role is more of a co-managerial role for protected areas, contrary to what the State has

expressed in its policy. In the end, "projects" replace the management that the administration is supposed to provide. The latent unease observed on this subject deserves to be the subject of a clear policy and standard memoranda of understanding with international organizations.

$\checkmark$ The division of forest management units (FMUs) and forest harvesting units

(SEU) was implemented in a reactive manner to address industry supply issues, whereas the concept of forest planning was originally intended. Recently, the redistribution operation establishing the new conventions has not been properly planned (Mpati B., 2006). The concept of useful areas only appeared in 2003 for reasons of fiscal weight (Itoua-Ngaporo. 2004).

$\checkmark \quad$ Greater efficiency and transparency require the establishment of a system of control that would allow compliant transactions to be established centrally in each FMU.

$\checkmark \quad$ The procedure for issuing annual cutting permits now seems to be under control. Knowing that that it constitutes an essential reference in terms of control, taxation and monitoring of developments, a modern management system allowing the availability in real time of management information (data and mapping) for all is necessary (REM. 2009). The Forest Code defined the roles and responsibilities of the various stakeholders, leading to institutional reform and the creation of the MEF, the Inspectorate General of Forest Economy (IGEF), the Service de contrôle des produits forestières destinés à l'exportation (SCPFE), the Société générale de surveillance (SGS), the Fonds forestier (FF) and the Centre national d'inventaire et d'aménagement des ressources forestières et fauniques (CNIAF). Despite the establishment of these structures and the adoption of legal standards, the effectiveness of forest law enforcement in Congo is confronted with the following problems identified by the mission to support the implementation of an independent observer (EMN, 2005):

- Forest law enforcement suffers from a lack of coordination between the different structures in charge

- which results in fragmentation and inconsistency of the bodies responsible for monitoring 
forestry activities (departmental directorates and their field brigades, the general inspection, the SCPFE, etc.);

- Structural questioning of the impartiality of the control activities of the directorates (both judging and judging the impact of some of its own activities);

- Communication channels between the main branches of the Ministry in charge of activities are not fluid due to their hierarchical complexity and a clear lack of interest in sharing information and analysis at certain levels (National REDD+ Strategy., 2013);

- The lack of a coherent planning cycle, synchronization of control, collection

information and analysis of the results hinders the effectiveness of the control;

- Current technological methods and tools -

Geographic Information Systems (GIS), positioning tools (Global Positioning System, GPS) and appropriate communication and IT tools - are only partially available and difficult to access within the Ministry. Their use and dissemination are not generally promoted;

- Cash flow problems and inflexible administrative

procedures make it difficult to

access to means of transport and financial means to carry out controls in a timely manner. In addition, there is a decrease in capacity due to an ageing workforce as well as a decrease in the number of sworn officers (REM. 2010);

- If we understand the cause of the economic difficulties facing the State, the framework

The regulatory framework for the implementation of forest law enforcement depends on law enforcement officials who can under no circumstances compete with the private sector's logistical resources. This seriously compromises the effectiveness and independence of control.

$>$ The main assets identified in terms of the involvement of local communities, indigenous peoples

and civil society in the forest resource management process in Congo can be summarized in the following points:

$\checkmark$ the particular emphasis on the participation of local communities, populations and communities and civil society in declarations and commitments made at various levels for the sustainable management of forests in the Congo Basin;

$\checkmark$ the principle of participation of local communities, indigenous peoples and the civil society to the forest resource management process recognized by law in Congo (Article 1 of the Forest Code); $\checkmark \quad$ the promulgation and publication of Law No. 52011 of 25 February 2011, promoting and publishing the protection of the rights of indigenous peoples. This law highlights Congo's desire to involve forest populations more strongly in the sustainable management of forest resources;

$\checkmark$ the implementation of mechanisms for the involvement of local communities, populations

and civil society in companies with developed (and certified) concessions and in some protected areas;

$\checkmark$ the effort to involve local communities, indigenous peoples and civil society

through the APV-FLEGT and the REDD+ process;

$\checkmark \quad$ the existence of a civil society structure in charge of independent observation;

$\checkmark$ The contribution of forests to the socio-economic development of the departments;

\section{5- Conclusion}

To be sustainable, forest governance in the Republic of Congo requires a policy orientation that restores capabilities limited by the denial of freedoms consubstantial to the colonial enterprise. However, post-colonial policies still struggle to take into account the individual as a social actor, which would make him or her socially more effective in managing natural resources, for the market and for development. Moving away from the colonial referent, by resolutely considering individuals as actors of social change, is a requirement of good forest governance, because to act in participatory interaction, one must be free and autonomous.

This ethical logic draws its resonance from the three categories of stylized facts analyzed, such as the induced effects of the governance of forest resources in the Republic of Congo, whose colonial embedding questions social justice. Equitable strengthening of the individual and collective capacities of local populations can be an effective means of targeting the most disadvantaged categories of actors among stakeholders, particularly because of their poorly taken into account aspirations. This implies deconstructing the widespread conception of the participatory approach, as a simple adherence, to the detriment of locally expressed life choices.

The recognition of grassroots communities, through their specific characteristics in terms of cultural differences and the particular conception of the relationship to the forest, therefore becomes an essential ethical consideration. Recognition is as much about accepting a priori the ways in which things work as it is about respecting the dignity of the people who wear them. This requires a real listening to the real aspirations to be and to do, without any 
value judgment. This is the whole meaning of the need for education for sustainable development.

Although independence has restored some formal rights, their exercise remains incomplete in terms of the conservation of the colonial foundations of forest governance by alternative governments.

It is not enough to develop a policy to ensure its success, but an administration and civil society actors capable of implementing it effectively are also needed. Its implementation and the achievements of the resulting action plan depend on many factors. Political will and commitment at the highest level are undoubtedly a prerequisite.

Issues, which are still crucial and include land tenure, the implementation of the rights of forest-dependent people (local and indigenous populations), etc., deserve particular attention to ensure the full success of forest policy.

Special efforts must be made to ensure coherence with the policies of other sectors, in particular land, agriculture, energy, mining, etc. Similarly, a real integration of international initiatives into the national context is also necessary, especially since the debate on forestry and environmental issues is topical.

The importance of involving public and private stakeholders at certain levels in the development processes and in the implementation of the policy and action plan is now recognized. Indeed, forest policy will have a greater opportunity to contribute to the green economy and poverty eradication when the support of all stakeholders is effective.

$>$ Recommendation for sustainable management of forest heritage in Congo

Sustainable management of the forest heritage requires the implementation of two parameters. The first concerns the application of legal texts and the second concerns the adoption of sociological measures by the Congolese public authorities.

A. Application of legal texts against the degradation of the forest heritage

The application of legal texts concerns the application of texts on Environmental Impact Assessment and the repression of forest offences.

$\checkmark$ Application of the texts on Environmental Impact

Assessment

$\checkmark$ Punishment of forest offences; Punishment of forest offences requires both criminalization and prosecution before the judge.
B. Adoption of sociological measures by the Congolese authorities

The sociological measures that the current Congolese forest sector, which at the same time benefits from a legal framework of public authorities, must adopt concern the application of participatory policies to the benefit of local communities, community management of forest resources by them and the promotion of environmental education in forest regions.

$\checkmark$ Application of participatory policies to the benefit of local communities

$\checkmark$ Community-based forest resource management by local communities

$\checkmark$ Promotion of Environmental Education in forest regions.

\section{References:}

1. ATLAS FORESTIER INTERACTIF DU CONGO (version 1.0): Document de synthèse. 2007

2. Le CNSEE, www.cnsee.org, 2006.

3. Rapport Forest Monitor, REM et CAGDF 2013 www.rem.org.uk /documents/ OIFLEG_FM_RF2013_ Congo.pdf.

4. La politique forestière de la République du Congo ,2014-2015.

5. COHEN (W.B.), 1971. - Rulers of Empire. - The French Colonial service in Africa. - Stanford : Hoover Institution Press - Stanford Univ. - 278 p. [Traduit en 1973. - Empereurs sans sceptre. - Paris: Berger Levrault].

6. HICKEL (R.), 1932. - Présentation des comptes rendus du Congrès de l'Union internationale des Instituts de Recherche forestière de Nancy, septembre 1932. - Comptes Rendus des Séances de l'Académie d'Agriculture de France,vol. XX, 1934, pp. 120-122 citant le discours d'ouverture de Ph. Guinier.

7. GUINIER (Ph.), 1952. - Préface à l'ouvrage « Sylviculture » de M. Perrin. - Nancy : École nationale des Eaux et Forêts. tome I, 318 p., pp.LX-XXII.

8. Si la priorité entre dimension économique et écologique fait souvent l'enjeu de débats, la dimension sociale est reléguée à un rôle subalterne, voire omise (Ballet et al., 2005).

9. NKODIA A., 2013. Diagnostic du secteur forestier en République du Congo. Rapport de consultation. FAO/MEFDD. $54 \mathrm{p}$.

10. La politique forestière de la République du Congo.; 2015.

11. République du Congo representation de la FAO cadre de la programmation pays 2013-2016

12. Politique forestière FAO, révision $\mathrm{IH}, 140906 ; 2015$.

13. N'ZALA, D., et Boukoulou, H., 2002. Evaluation des besoins en formation forestière au Congo. Rapport de consultation FAO/RIFFEAC/UICN. 79p

14. STADS, G. J., G. Bani et A. Itoua-Ngaporo. 2004. La République du Congo. Abrégé de l'ASTINo. 20. Washington, D.C. et Brazzaville: Institut international de recherche sur les politiquesalimentaires et Délégation générale à la recherche scientiique et technique.

15. PARFAIT OUMBA.; Développement durable et gestion des forêts du bassin du Congo: étude comparative des politiques forestières du Cameroun et de la République du Congo.;2007.

16. Dumont, 1962, pp. 169-170.

17. GIREAUD (P.N.), Aménagement durable des forêts d'Afrique centrale, projet d'article « histoire des développements », Serge Michailof éd. mai 2005.

18. Parcs et réserves du Congo; 2012.Evaluation de 1'efficacité de la gestion des aires protégées. 
19. Mpati B., 2006. Rapport sur la situation des capacités nationales en matière d'évaluation des ressources forestières et les besoins en formation, de recyclage et de renforcement des capacités du CNIAF/ FAO.

20. STRATEGIE NATIONALE REDD+ DE LA REPUBLIQUE DU CONGO.;2016.

21. Rapport Forest Monitor, REM et CAGDF 2013: www.rem.org.uk /documents/ OIFLEG _FM_RF2013_ Congo.pdf.

22. PARKER, M., 2004. West and Central Africa: Progress and prospects for forest certification. Forest Trends, Washington D.C., USA.

23. SANTOIR C., 1992, Sous l'empire du cacao. Étude diachronique de deux terroirs camerounais, Paris, Orstom.

24. BERKES, F. 'The Problematique of Community-Based Conservation in a Multi-Level World', Mimeo, University of Manitoba. 2006

25. Les communautés locales et populations autochtones (CLPA) sont de plus en plus en marge de l'économie formelle et de la prise de décision concernant l'utilisation des ressources naturelles et elles sont confrontées à une insécurité foncière croissante.

26. (Mise en œuvre de la foresterie communautaire en République du Congo, 2017).

27. Ballet, J., Koffi, K.J.M., Komena, K.B. (2010). 'Responsibility for the forest in Côte d'Ivoire: where are we now?' International Journal of Sustainable Society, 2(1) : 70-84.
28. Andriananja, H., Radja, K., Sirven, N. (2006). 'Réseaux de parenté de Majakatompo, la gestion communautaire de la forêt'. Économie Rurale, 294-295: 27-40.

29. Kouamékan J.M. Koffi Les Faits stylisés de la gouvernance forestière en Afrique Subsaharienne Francophone : déni de libertés et enjeux de soutenabilité .2014

30. FAO (2007). Rapport sur la situation des forêts dans le monde, Rome.

31. Les forêts du bassin du Congo - État des Forêts 2010. Eds : de Wasseige, C., de Marcken P., Bayol N., Hiol Hiol F. et Mayaux Ph., Desclée B., Nasi R., Billand A., Defourny P. et Eba'a Atyi R. - 2012.

32. The Forests of the Congo Basin - State of the Forest 2008, Editors : de Wasseige C., Devers D., de Marken P., Eba'a Atyi R., Nasi R. and Mayaux Ph. - 2009. Food and Agriculture Organization of the United Nations (FAO). 2010. Évaluation des ressources forestières mondiales, 2010 : Rapport national du Congo. Rome : FAO.

33. Resource Extraction Monitoring (REM). 2009. Évolution du contrôle et des sanctions de l'exploitation forestière illégale en République du Congo: Rapport annuel de l'OI-FLEG au Congo. Cambridge : REM.

34. Resource Extraction Monitoring (REM). 2010. Le parcours des données forestières en République du Congo.

35. Cambridge : REM. World Resources Institute (WRI). 2007. Atlas forestier interactif du Congo version 1: Document de synthèse. Washington, DC : WRI. 